\title{
Sodium/Glucose Cotransporter 1
}

National Cancer Institute

\section{Source}

National Cancer Institute. Sodium/Glucose Cotransporter 1. NCI Thesaurus. Code C77168.

Sodium/glucose cotransporter 1 ( $644 \mathrm{aa}, \sim 73 \mathrm{kDa}$ ) is encoded by the human SLC5A1 gene. This protein is involved in the active transport of glucose and galactose into cells. 